geographical material in the authors with whom he deals. Nevertheless, he certainly demonstrates that geography is a significant and integral feature of the writing of this period.

University of Manchester

A.T. FEAR

andrew.fear@manchester.ac.uk

\title{
THE HISTORY OF HISTORY
}

\begin{abstract}
Christ (K.) Klios Wandlungen. Die deutsche Althistorie vom Neuhumanismus bis zur Gegenwart. Pp. 288. Munich: C.H. Beck, 2006.
\end{abstract} Cased, €44.90. ISBN: 978-3-406-54181-0.

doi:10.1017/S0009840X07000820

In the midst of World War I, the German historian Friedrich Meinecke said that classical scholars were the odd ones out, because they proved to be unaffected by political events. Nearly 100 years later, the German historian Karl Christ has succeeded in refuting that popular fallacy. In his most recent book, on 'Clio's metamorphoses', he reconstructs the manifold interrelations between everyday politics and classical scholarship and places ancient historians in the political and cultural contexts of the nineteenth and twentieth centuries. C. takes stock of his own research into the history of German historiography of the ancient world, which goes back to the late sixties of the last century. When the students revolted, the liberal ancient historian produced a programme to study the development of his discipline in Germany, encouraging one of his doctoral students to explore the situation of Ancient History in Germany from 1933 to 1945. Volker Losemann's resulting thesis Nationalsozialismus und Antike: Studien zur Entwicklung des Faches Alte Geschichte 1933-1945 (Hamburg, 1977) shocked the conservative establishment, initiated further research, and is now recognised as a standard work.

Through his writing and teaching $C$. has succeeded in founding the Wissenschaftsgeschichte of Ancient History in Germany. He was determined to emphasise the importance of his subject at a time when most of his colleagues still thought that the critical history of research into Antiquity was equivalent to reverential hagiography or tedious doxography. C. has strengthened the selfconfidence of young ancient historians to explore the history of classical scholarship, and this approach has borne fruit in German-speaking countries, as the pages of his book dedicated to the progress of Ancient History during the last 30 years impressively show. Today, the history of historiography as well as Rezeptionsgeschichte and Wissenschaftsgeschichte are part and parcel of Ancient History at almost all universities in Germany, Austria and Switzerland.

C. needs less than 160 pages of text to give a succinct and concise sketch of the history of Ancient History from the beginning of the nineteenth century to the present. His elegant survey, the focus of which is on Germany, may deserve an English translation. What picture emerges? The neo-humanist universities, shaped by the reforms of Wilhelm von Humboldt, were governed by the programme of Altertumswissenschaft, which had a lasting influence on classical studies throughout the Western world, and represented a profound break in the exploration of antiquity. This programme demanded objectivity as its fundamental principle, believed in the inherent significance of historical events, and emphasised the role of the individual. Following the lead of Barthold Georg Niebuhr and August Boeckh, numerous

The Classical Review vol. 57 no. 2 (C) The Classical Association 2007; all rights reserved 
authors saw the central aim of classical studies as cognitio totius antiquitatis, that is, an understanding of the classical heritage in its entirety. Prodigious joint ventures Corpora, Monumenta and Thesauri-made the legacy of the ancient world accessible. Faith in progress and scientific optimism characterised this new, professionalised study of antiquity at German universities and academies.

During the later part of the nineteenth and the early part of the twentieth century, however, an awareness of an impending crisis spread throughout the world of classical studies, just as it did in other disciplines. Critics condemned the sterile objectiveness of antiquated research, and, under the influence of Jacob Burckhardt and Friedrich Nietzsche, intellectual dissidents questioned the legitimacy of classical scholarship that concentrated on positivist results and whose historical relativism undermined any normative understanding of antiquity. German and Austrian authors were in search of new concepts, which were meant to supersede the technical scholarship of nineteenth-century historicism, reconcile scholarship and everyday life, and rehabilitate antiquity as a relevant historical entity. Seeking a new image of antiquity, some historians went on to support the National Socialist state, and individual scholars such as Helmut Berve and Wilhelm Weber even interpreted Greek and Roman history by utilising racist categories. But C. is certainly correct in emphasising that the majority of ancient historians did not adopt racist and anti-Semitic theories advocated by National Socialist dogma.

After the end of the Second World War Germany was divided; and so was Ancient History. In the Federal Republic of Germany post-war studies were characterised by restorative tendencies, and the National Socialist past of the discipline was assiduously ignored. In the German Democratic Republic some authors tried to wipe the slate clean and to start again. But their studies of class relations and ideology followed orthodox Marxist historiography too closely and could not substantially contribute to modern classical scholarship. The Cold War aggravated the tensions between Marxist and 'bourgois' Ancient History. Whilst in West Germany the discipline has benefited from the extension of the university system since the 1950s, it just managed to stay alive in East Germany.

C. outlines these developments by reconstructing individual biographies. He concentrates his attention not only on celebrities such as Theodor Mommsen and Eduard Meyer, Joseph Vogt and Alfred Heuß, but also describes the life and auvre of less well-known scholars. He offers a complex representation of Ancient History in Germany depicting individual achievements - and failings - as well as political behaviour under different historical conditions. C. does not like polemical judgements and ideological skirmishes. He trusts in the significance of literal quotations. And he is cautious even about condemning those who profited from their affiliation with a totalitarian system. But his deep sympathy goes out to those scholars who were marginalised and ostracised in the 'Third Reich' and in the German Democratic Republic.

In his book C. reflects the stage which discussion of the history of classical scholarship and especially of Ancient History has reached, and specifies the desiderata. There is still a lot of work to be done. Personal papers and official correspondences are to be collected and edited, many written sources must be evaluated and discussed. At first, there will be no alternative to what C. calls Wissenschaftlergeschichte (the history of individual scholars). Only when the biographies are reconstructed, the intellectual and scientific basis of their work is understood, and the contemporary political impacts are assessed, can a comprehensive account of the history of Ancient History - and classical scholarship - in Germany be written. 
Arnaldo Momigliano, whose importance for Wissenschaftsgeschichte C. does not cease to emphasise, was correct in saying that everyone interested in the history of scholarship must be able to comprehend both the lives and times of the authors, and the topics they have studied. C. meets that prerequisite better than anybody else.

Universität Bern

STEFAN REBENICH

stefan.rebenich@hist.unibe.ch

\section{AEGEAN PREHISTORY}

Finkelberg (M.) Greeks and Pre-Greeks. Aegean Prehistory and Greek Heroic Tradition. Pp. xvi + 203, figs, maps. Cambridge: Cambridge University Press, 2005. Cased, £48, US\$85. ISBN: 978-0-521-85216-6. doi:10.1017/S0009840X07000832

The creation of 'Hellenic' identity is a remarkable cognitive achievement of the Archaic period. Despite political fragmentation organised in a variety of regional systems between poleis and ethnê (see most recently C. Morgan, Early Greek States Beyond the Polis [Cambridge, 2003]) the population of seventh to sixth century B.C. Greece from Thessaly to Crete and to Western Asia Minor managed to entertain and to sustain the idea of common descent, language, religion and history.

The main thesis of F.'s book is, according to the blurb, 'that the Greeks started their history as a multi-ethnic population group consisting of both Greek-speaking newcomers and the indigenous population of the land, and that the body of "Hellenes" as known to us from the historic period was a deliberate self-creation'. She develops her argument in eight chapters:

1. The 'Introduction' (pp. 1-23) outlines the concept of the book and offers some methodological insights. On p. 9 F. makes clear that the historical information which is contained in the Mycenaean Linear B texts is scarce in comparison with the written documents of the contemporary Near East. 'What the student of Greek prehistory has instead are literary sources originating in oral tradition. While it goes without saying that this tradition should not be treated on equal footing with documentary sources nor used without being correlated with archaeological and linguistic evidence, it can nevertheless be employed with profit for the reconstruction of history.' There is a brief review of recent ideas and discussions of concepts of ethnicity and group identity.

2. 'The Heterogeneity of Greek Genealogy' (pp. 24-41) explains that not all the heroes of Greek legend were regarded as 'descendants of Hellen'. Rather than founding their group identity on belief in a common descent, the body of Hellenes perceived itself as an ethnically heterogeneous group.

3. 'The Pre-Hellenic Substratum Reconsidered' (pp. 42-64). Evidence for an assumed pre-Hellenic population of Greece comes from words containing the linguistic suffixes -ss- and -nth-. F. takes the occurrence of these suffixes in the languages of Anatolia to indicate that the so-called pre-Hellenic populations of Greece were of Anatolian stock.

4. 'Kingship in Bronze Age Greece and West Asia' (pp. 65-89). In this chapter F. argues on the basis of the Greek mythical genealogies and king-lists that royal succession in Bronze Age Greece followed a matrilinear, exogamous dynastic system.

The Classical Review vol. 57 no. 2 (C) The Classical Association 2007; all rights reserved 